\title{
Effect of treating morbid obesity by intragastric balloon implantation on patients' multimorbidity
}

\author{
Wpływ leczenia otyłości olbrzymiej metodą implantacji balonu \\ wewnątrzżołądkowego na wielochorobowość pacjentów \\ Karolina Krupa-Kotara' ${ }^{1}$, Małgorzata Olejniczak-Nowakowska (iD), Stanisław Kotara, Krystyn Sosada² \\ ${ }^{1}$ Department of Epidemiology and Biostatistics, School of Health Sciences in Bytom, \\ Medical University of Silesia in Katowice, Poland \\ 2Department of Emergency Medicine, School of Medical Sciences in Katowice, \\ Medical University of Silesia in Katowice, Poland
}

\begin{abstract}
INTRODUCTION: Morbid obesity and its accompanying multimorbidity constitute a significant public health problem. AIM: The aim of the study is to evaluate the effect of endoscopic implantation of an intragastric balloon on the ailments and associated diseases in people with obesity.

MATERIAL AND METHODS: The study included 75 people treated by intragastric balloon implantation. The sample selection was purposeful. The patients were qualified for balloon implantation, according to recognized indications for the endoscopic treatment of obesity. All the analyses were performed using Statistica 12. Results for which $\mathrm{p}<0.05$ were considered as statistically significant.

RESULTS: Positive effects of the treatment of obesity by intragastric balloon implantation in relation to comorbidities were observed in 54 patients (62\%), 30 people (40\%) achieved minimal health improvement, the regression of one serious disease and alleviation others in 24 patients $(32 \%) .21$ patients $(28 \%)$ had no improvement in their health status. None of the patients reported the resolution of all major diseases, but there was also no deterioration in the health of any patient. There was a statistically significant reduction in the incidence of hypertension, type 2 diabetes, spinal pain, osteoarthritis, sleep apnoea, menstrual disorders, impotence and dyspnoea during IGB treatment.

CONCLUSIONS: Treatment by endoscopic implantation of an intragastric balloon alleviates the course or reduces the incidence of concomitant diseases in persons with morbid obesity.
\end{abstract}

\section{KEY WORDS}

morbid obesity, intragastric balloon, multimorbidity

Received: 21.11.2019 Revised: 25.11.2019 Accepted: 25.11.2019 Published online: 11.09.2020

Address for correspondence: Dr n. med. Karolina Krupa-Kotara, Zakład Epidemiologii, Katedra Epidemiologii i Biostatystyki, Wydział Nauk o Zdrowiu w Bytomiu, Śląski Uniwersytet Medyczny w Katowicach, ul. Piekarska 18, 41-902 Bytom, tel. +48 3239 76 532, e-mail: kkrupa@sum.edu.pl

Copyright $\odot$ Śląski Uniwersytet Medyczny w Katowicach

www.annales.sum.edu.pl 


\section{STRESZCZENIE}

WSTĘP: Otyłość olbrzymia i towarzysząca jej wielochorobowość stanowią poważny problem zdrowia publicznego.

CEL: Celem pracy jest ocena wpływu endoskopowej implantacji balonu wewnątrzżołądkowego na dolegliwości i choroby towarzyszące u osób $\mathrm{z}$ otyłością.

MATERIAŁ I METODY: Badaniem objęto 75 osób leczonych metodą implantacji balonu wewnątrzżołądkowego. Pacjenci zostali zakwalifikowani do implantacji balonu, zgodnie z uznanymi wskazaniami do endoskopowego leczenia otyłości. Wszystkie analizy przeprowadzono za pomocą Statistica 12. Za poziom istotności statystycznej przyjęto p $<0,05$. WYNIKI: Pozytywne efekty leczenia otyłości metodą implantacji balonu wewnątrzżołądkowego w odniesieniu do współistniejących chorób zaobserwowano u 54 pacjentów (62\%), 30 osób (40\%) osiągnęło minimalną poprawę stanu zdrowia, u 24 pacjentów (32\%) ustąpiło co najmniej jedno zasadnicze schorzenie. 21 pacjentów (28\%) nie wskazywało poprawy stanu zdrowia. Żaden z pacjentów nie zgłosił ustąpienia wszystkich głównych chorób, ale również nie nastąpiło pogorszenie stanu zdrowia. Podczas leczenia IGB stwierdzono statystycznie istotne zmniejszenie występowania nadciśnienia, cukrzycy typu 2, bólu kręgosłupa, choroby zwyrodnieniowej stawów, bezdechu sennego, zaburzeń miesiączkowania, impotencji i duszności.

WNIOSKI: Leczenie otyłości metodą endoskopowej implantacji balonu wewnątrzżołądkowgo zmniejsza częstość współistniejących chorób u osób z otyłością olbrzymią.

\section{SŁOWA KLUCZOWE}

otyłość olbrzymia, balon wenątrzżołądkowy, wielochorobowość

\section{INTRODUCTION}

Morbid obesity and its accompanying multimorbidity constitute a significant public health problem. It is a systemic, multifactorial, progressive, chronic metabolic disease, resulting from the imbalance between energy intake and loss, the so-called energy homeostasis of the body. The effect of these disorders is excessive accumulation of body fat. As the process intensifies, pathologies and dysfunctions of all the organs and systems appear, leading to deterioration in the quality of life, risk of the coexistence of illnesses, and increased risk of premature death as time goes on. The development of obesity is influenced by genetic factors, environmental factors, including lifestyle, stress and other factors such as hormonal disorders or the use of certain medications. Obesity, which accounts for about $98 \%$ of cases, is caused by excessive food supply in relation to energy expenditure [1]. Overweight and obesity ranks fifth among the risk factors for non-communicable chronic diseases responsible for the number of deaths in the world [2]. The number of people with excess body weight is about 1.9 billion worldwide, of which about 600 million are obese [3]. It is estimated that by 2030 the number of obese people with a BMI $\geq 30 \mathrm{~kg} / \mathrm{m}^{2}$ will increase by $33 \%$, while obesity with a BMI $\geq 35 \mathrm{~kg} / \mathrm{m}^{2}$ by $130 \%$ [4]. Bariatric surgery classifies obesity into morbid obesity $=\mathrm{BMI}$ $>40 \mathrm{~kg} / \mathrm{m}^{2}$ and super obesity - BMI $>50 \mathrm{~kg} / \mathrm{m}^{2}$, which are not subject to effective dietary and pharmacological treatment and are indications for surgical treatment [5]. As demonstrated by the largest obese population study to date, Swedish Obesity Subjects (SOS), surgical treatment offers a chance for long-term weight loss and overall mortality reduction. The Swedish study showed a loss of excess body weight $14-25 \%$ depending on the performed procedure performed over in a 10 -year period and a $29 \%$ reduction in mortality based on the hazard ratio $\mathrm{HR}=0.71$ compared to standard weight reduction methods [6,7]. In the case of morbid obesity, surgical treatment has a significant advantage over conservative treatment [8]. However, due to the complications and costs associated with bariatric surgery, the search for alternative, less invasive methods of treatment has started [9]. Endoscopic treatment of obesity is based on the implantation of an intragastric balloon (IGB) filled with fluid or air. The main advantage of the endoscopic approach is its reversibility and its less invasive character compared to bariatric surgery. The disadvantage, however, is mostly the transient reduction of excess weight $[10,11]$. The number of bariatric procedures in relation to the population of Poland is only $0.0033 \%(0.42 \%)$ compared to the population of people with obesity) and it seems insufficient [12]. In the opinion of experts, the intragastric balloon is a very good method of weight reduction and should be used in patients with morbid obesity, who due to their current state of health are not eligible for many hours of bariatric surgery [13].

\section{AIM}

The aim of the study is to evaluate the effect of endoscopic implantation of an intragastric balloon on the ailments and associated diseases in people with obesity.

\section{MATERIAL AND METHODS}

The study included 75 people treated by intragastric balloon implantation with a median age of $51(21=71)$, including 38 women and 37 men. The characteristics of the study group are shown in Table I. 
Table I. Characteristics of study group Tabela I. Charakterystyka grupy badanej

\begin{tabular}{|c|c|c|}
\hline & Variable & $\mathrm{n}(\%)$ \\
\hline \multirow{2}{*}{ 爻 } & woman & $38(50.7 \%)$ \\
\hline & man & $37(49.3 \%)$ \\
\hline \multirow{4}{*}{ 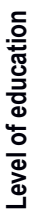 } & primary education & $2(2.7 \%)$ \\
\hline & vocational education & $15(20.0 \%)$ \\
\hline & secondary education & $51(68.0 \%)$ \\
\hline & university education & $7(9.3 \%)$ \\
\hline \multirow{5}{*}{ 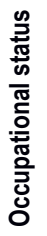 } & student & $3(4.0 \%)$ \\
\hline & employed & $29(38.7 \%)$ \\
\hline & unemployed & $7(9.3 \%)$ \\
\hline & disabilty pension & $31(41.3 \%)$ \\
\hline & retired & $5(6.7 \%)$ \\
\hline \multirow{5}{*}{ 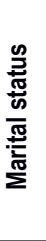 } & unmarried & $15(20.0 \%)$ \\
\hline & married & $48(64.0 \%)$ \\
\hline & in a relationship & $5(6.7 \%)$ \\
\hline & divorced & $4(5.3 \%)$ \\
\hline & widow/widower & $3(4.0 \%)$ \\
\hline \multirow{4}{*}{ 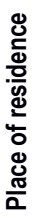 } & village & $19(25.3 \%)$ \\
\hline & city up to 50000 & $15(20.0 \%)$ \\
\hline & city of 50000 to 100000 & $11(14.7 \%)$ \\
\hline & city over 100000 & $30(40.0 \%)$ \\
\hline
\end{tabular}

The primary advantage of this method is its reversibility and minimally invasive nature compared to bariatric surgery procedures, whereas its key disadvantage is frequently the impermanent loss of excess body mass. The indications for the treatment of obese patients with endoscopic intragastric balloon implantation are presented in Table II [11].

Table II. Indications for obesity treatment using endoscopic intragastric balloon (IGB) implantation

Tabela II. Wskazania do leczenia otyłości z zastosowaniem endoskopowe implantacji balonu wewnątrż̇ołądkowego (IGB)

\begin{tabular}{ll}
\hline $\begin{array}{c}\text { Body Mass } \\
\text { Index }\end{array}$ & \multicolumn{1}{c}{ Indications } \\
\hline $\mathrm{BMI}<35 \mathrm{~kg} / \mathrm{m}^{2}$ & $\begin{array}{c}\text { - diseases accompanying obesity } \\
\text { - ineffective conservative treatment for period of at } \\
\text { least } 3 \text { years } \\
- \text { contraindications for pharmacological obesity } \\
\text { treatment }\end{array}$ \\
\hline $\mathrm{BMI} \geq 35 \mathrm{~kg} / \mathrm{m}^{2}$ & $\begin{array}{c}\text { - ineffective conservative treatment } \\
- \text { diseases accompanying obesity } \\
- \text { contraindications for bariatric surgical procedure or } \\
\text { no consent of patient for such treatment }\end{array}$ \\
\hline $\mathrm{BMI} \geq 40 \mathrm{~kg} / \mathrm{m}^{2}$ & $\begin{array}{l}\text { - perioperative risk in obese patients requiring } \\
\text { surgery, in particular bariatric, surgical, } \\
\text { cardiosurgical and orthopaedic procedures }\end{array}$ \\
\hline $\mathrm{BMI} \geq 50 \mathrm{~kg} / \mathrm{m}^{2}$ & $\begin{array}{c}\text { - initial eligibility of patients for restrictive bariatric } \\
\text { surgical procedure ('BIB test') }\end{array}$ \\
\hline
\end{tabular}

\section{Study inclusion criteria}

Patients with a BMI value above $40 \mathrm{~kg} / \mathrm{m}^{2}$ were qualified for implantation. The purpose of intragastric balloon implantation was to reduce the excess body mass of the patients to improve their cardiorespiratory function and reduce the perioperative risk during the planned bariatric surgery procedure. The condition for including the patients in the procedure was complete understanding of the risks and restrictions related to the surgical treatment of obesity and written consent of the patient to observe the treatment regimen in the pre- and post-operative period that is compulsory in the clinic. The eligibility criteria for treatment with the intragastric balloon also included a documented failure of previous attempts of conservative obesity treatment and the absence of psychological disorders preventing indispensable cooperation with a physician and regular outpatient follow-ups.

\section{Study exclusion criteria}

Patients with obesity caused by hormonal disorders were excluded from the endoscopic treatment of morbid obesity. In addition, patients with a Helicobacter pylori infection confirmed with the urease test, a peptic or duodenal ulcer in the history, after gastroesophageal reflux surgery, with a potential digestive bleeding focus (oesophageal varices, telangiectases, congenital digestive anomalies), with grade 3 oesophagitis, or Barrett's oesophagus $>5 \mathrm{~cm}$ were excluded from the study. The procedure was not performed in patients with non-specific enteritides, after digestive surgery, with cirrhosis or chronic renal insufficiency either. Patients addicted to alcohol or drugs, taking antithrombotic or anti-inflammatory drugs on a continuous basis, patients with AIDS, a malignant tumour and pregnant females were also excluded from the procedure.

\section{Intragastric balloon implantation method}

All the patients eligible for the procedure underwent the necessary laboratory tests, including a blood type and Rh factor test, HCV, HbSAg and USR tests. The other tests included ECG, chest X-ray, spirometry with optional sleep apnoea diagnostics, abdominal ultrasound and panendoscopy with the urease test. Before the procedure, all the patients were consulted by a psychologist, endocrinologist and dietary specialist. Additional consultations included laryngological and - for females - gynaecological consultations to diagnose and possibly treat any inflammatory focuses which might pose a potential source of septic complications in the postoperative period.

The balloon - The BioEnterics Intragastric Balloon (BIB $\left.{ }^{R}\right)$ is implanted in a fasted patient upon sedation and local pharyngeal anaesthetics with a $4 \%$ lignocaine solution using an Olympus GIF Q165 video gastroscope. 
Once the balloon is deployed into the stomach, its accurate placement is assured, and the balloon is filled with an $0.9 \% \mathrm{NaCl}$ solution mixed with methylene blue up to the maximum total volume of $700 \mathrm{ml}$. The balloon was inflated slowly on a continuous basis to prevent high pressure in the valve. The inflated balloon should move unrestrainedly within the stomach. Then a syringe is used to generate negative pressure in the filling catheter in order to close the valve and control its tightness. The valve is not tight when, after inflating the balloon, more than $5 \mathrm{ml}$ of fluid aspirates via the catheter. Before disconnecting the catheter and removing the panendoscope, the position of the balloon, in particular against the outlet and with a view to no impaction within the stomach, is assessed. In the postoperative period the patients were ordered to comply with the following:

- hyoscine butylbromide $5 \mathrm{mg}$ every $6 \mathrm{~h}$ for 3 days after the procedure,

- a proton pump inhibitor, in a dose of $40 \mathrm{mg}$ /day for 2 days after the procedure, followed by $20 \mathrm{mg} /$ day for 15 days,

- in case of vomiting, metoclopramide hydrochloride $60-40 \mathrm{mg} / \mathrm{day}$,

- follow-up visits in the 1st, 2nd and 4th week after the procedure, followed by monthly visits; - follow-up abdomen ultrasound in the 3rd month after the procedure to assess the balloon volume. In the postoperative period, the patients were obliged to observe the following dietary treatment regime:

- for the first 3 days after the procedure a liquid or semi-liquid diet, 3-4 meals a day, at least a $1 \mathrm{~h}$ interval between meals, avoiding spices, coffee, sweets and cold dishes. Drink 1000-1500 ml of liquids a day,

- from the 4th day after the procedure, gradual switching towards a solid diet. In case of vomiting, return to a semi-liquid diet for three consecutive meals. Three to four meals a day, avoiding drinking during meals, sparkling mineral water and coffee, sweets, olive oil and other high calorie meals.

\section{Intragastric balloon removal method}

The balloon was removed at 6 months (192 days) after implantation. Before the procedure, the patients were ordered to switch to a liquid diet for 3 days. The balloon was removed from the stomachs of fasted and sedated patients with a panendoscope. After perforation of the balloon using a steel guidewire ended with a needle and catheter, its content was suctioned. Once the balloon was completely empty, its wall was snapped with forceps in the place opposite to the valve and removed gently from the digestive tract.

Weight loss was assessed on the basis of the percentage of excess body weight loss (\%EWL) and the difference in baseline BMI before and after treatment (EBMIL - excess BMI loss) [14]. They were divided into 11 groups according to the recommendations of the American Obesity Association and the Shape UP America Foundation in order to systematize the additional burden of disease in the study [15]. The change in health status was assessed according to the scale: deterioration of health, lack of influence on health status, improvement of health status, resolution of one of serious illnesses and alleviation of others, resolution of all major diseases according to the BAROS scale (Bariatric Analysis and Reporting Outcome System) developed by Oria and Moorehead [15].

In the statistical analysis, statistical methods for full population surveys of general statistical units were used, according to the analysed statistical characteristics. The Shapiro-Wilk test was used to assess the compatibility of the distribution of variables with the normal distribution. The relationships between the analysed parameters were assessed using the V-square test. All the analyses were performed using Statistica 12. Results for which $\mathrm{p}<0.05$ were considered statistically significant.

\section{RESULTS}

In the Department of General and Bariatric Surgery and Emergency Medicine, School of Medicine with the Division of Dentistry in Zabrze, Medical University of Silesia in Katowice, 83 intragastric balloon implantations were performed in obese patients from March 15, 2014 to September 30, 2016. Of the 83 people treated with the intragastric balloon, two people died during treatment due to circulatory and respiratory failure not directly related to treatment. Another four people died in the period after the end of treatment; the cause of death reported by the families was complications of chronic diseases. Two people did not agree to participate in the study for personal reasons, or because of the unsatisfactory, in their opinion, weight loss after surgery and the resulting reluctance to cooperate further.

The weight changes in the patients after IGB treatment were analysed (Tab. III).

The mean body mass excess was higher in the group of male patients $100.0 \pm 25.4$ than in the women 94.5 \pm 25.4 , and these differences were statistically significant $(\mathrm{p}<0.001)$. The percentage of excess weight loss $(\%$ EWL) was calculated as a recommended measure for surgical treatment. The mean percentage of excess weight loss was $29.1 \pm 13.7 \%$ and was similar for both groups; women $29.4 \pm 13.7 \%$ and men $28.8 \pm 13.9 \%$.

The effect of excess weight loss after IGB treatment was observed. The highest number of patients 41 (55\%) achieved a loss of excess body weight in the $25.0-49.9 \%$ range, another $30(40 \%)$ patients had a loss of excess body weight in the $0.0-29.9 \%$ range, 4 patients attained a loss of excess body weight in the 50.0-75.0\% range. During IGB treatment no weight gain occurred in any patient. There was a significant decrease in BMI of $9.6 \pm 5.2 \mathrm{~kg} / \mathrm{m}^{2}(16.6 \%)(\mathrm{p}<0.0001), 9.5 \pm 4.5 \mathrm{~kg} / \mathrm{m}^{2}$ $(16.4 \%)$ for men (NS), $9.6 \pm 5.9 \mathrm{~kg} / \mathrm{m}^{2}(16.6 \%)$ for women (NS) after 6 months of intragastric balloon treatment. The difference in BMI before and after treatment (EBMIL - excess BMI loss) was $29.2 \pm 13.8 \mathrm{~kg} / \mathrm{m}^{2}$.

According to the body mass index, the patients were divided into two groups; the first group consisted of BMI $<50 \mathrm{~kg} / \mathrm{m}^{2}$ (morbid obesity) and the other group 
with $\mathrm{BMI} \geq 50 \mathrm{~kg} / \mathrm{m}^{2}$ (super obesity). In the study population, BMI $<50 \mathrm{~kg} / \mathrm{m}^{2}$ before IGB was observed in 10 subjects $(13 \%)$, while after treatment in 42 patients $(56 \%)$, the level of BMI $\geq 50 \mathrm{~kg} / \mathrm{m}^{2}$ was found before IGB treatment in 65 patients $(87 \%)$, and in 33 patients (44\%) after the treatment.

Positive effects of treatment of obesity by intragastric balloon implantation in relation to comorbidities were observed in 54 patients $(62 \%)$, including 30 people $(40 \%)$ who achieved minimal health improvement, the regression of one serious disease and alleviation others in 24 patients (32\%). 21 patients $(28 \%)$ had no improvement in their health status. None of the patients reported the resolution of all major diseases, but there was also no deterioration in the health of any patient. There was a statistically significant reduction in the incidence of hypertension, type 2 diabetes, spinal pain, osteoarthritis, sleep apnoea, menstrual disorders, impotence and dyspnoea during IGB treatment (Tab. IV).

The effects of changes in BMI and \%EWL on the incidence of post-treatment comorbidities were assessed. Neither the change in BMI or $\%$ EWL between the groups of patients (based on the incidence of accompanying complaints) was statistically significant.

The analysis did not show a statistically significant relationship between BMI $\left(<50\right.$ or $\left.\geq 50 \mathrm{~kg} / \mathrm{m}^{2}\right)$ after

Table III. Characteristics of study group before and after IGB treatment considering weight changes Tabela III. Charakterystyka grupy badanej przed i po leczeniu metodą IGB z uwzględnieniem zmian masy ciała

\begin{tabular}{|c|c|c|c|c|}
\hline \multirow{2}{*}{ Variable } & \multicolumn{4}{|c|}{ Study group } \\
\hline & Population & Women & Men & \multirow{2}{*}{$\begin{array}{l}\text { p-value } \\
\text { W vs. M }\end{array}$} \\
\hline $\mathrm{N}$ & 75 & 38 & 37 & \\
\hline Age & $\begin{array}{c}51.0 \\
(2171)\end{array}$ & $\begin{array}{c}50.0 \\
(28-71)\end{array}$ & $\begin{array}{c}52.0 \\
(21-65)\end{array}$ & NS \\
\hline Body mass before IGB [kg] & $\begin{array}{c}167.1 \pm 28.2 \\
(105.0-249.0)\end{array}$ & $\begin{array}{c}156.7 \pm 26.4 \\
(105.0-214.0)\end{array}$ & $\begin{array}{c}177.8 \pm 26.2 \\
(135.0-249.0)\end{array}$ & \multirow{2}{*}{$<0.0001$} \\
\hline Body mass after IGB [kg] & $\begin{array}{c}139.7 \pm 24.4 \\
(140.0-190.0)\end{array}$ & $\begin{array}{l}131.1 \pm 24.4 \\
(85.0-190.0)\end{array}$ & $\begin{array}{c}148.5 \pm 21.4 \\
(103.0-187.0)\end{array}$ & \\
\hline Weight change [kg] & $\begin{array}{c}27.4 \pm 14.8 \\
(0.0-62.0)\end{array}$ & $\begin{array}{c}25.6 \pm 12.3 \\
(0.0-50.0)\end{array}$ & $\begin{array}{c}29.4 \pm 17.0 \\
(2.0-62.0)\end{array}$ & NS \\
\hline Excess weight [kg] & $\begin{array}{c}94.5 \pm 25.4 \\
(39.4-171.5)\end{array}$ & $\begin{array}{c}89.2 \pm 25.4 \\
(39.4-159.8)\end{array}$ & $\begin{array}{c}100.0 \pm 254 \\
(25.4-171.5)\end{array}$ & $<0.001$ \\
\hline Excess body weight loss [\%] & $\begin{array}{c}29.1 \pm 13.7 \\
(0.0-69.4)\end{array}$ & $\begin{array}{c}29.4 \pm 13.7 \\
(0.0-57.4)\end{array}$ & $\begin{array}{c}28.8 \pm 13.9 \\
(2.1-69.4)\end{array}$ & NS \\
\hline BMI before IGB $\left[\mathrm{kg} / \mathrm{m}^{2}\right]$ & $\begin{array}{c}57.8 \pm 9.7 \\
(40.0-99.0)\end{array}$ & $\begin{array}{c}58.3 \pm 9.9 \\
(40.0-99.0)\end{array}$ & $\begin{array}{l}57,3 \pm 9,6 \\
(42,6-80,4)\end{array}$ & \multirow{2}{*}{$<0.0001$} \\
\hline BMI after IGB $\left[\mathrm{kg} / \mathrm{m}^{2}\right]$ & $\begin{array}{l}48.3 \pm 8.1 \\
(32.8-87.9)\end{array}$ & $\begin{array}{c}48.7 \pm 9.2 \\
(33.2-87.9)\end{array}$ & $\begin{array}{c}47.7 \pm 6.8 \\
(32.8-60.4)\end{array}$ & \\
\hline BMI change $\left[\mathrm{kg} / \mathrm{m}^{2}\right]$ & $\begin{array}{c}9.6 \pm 5.2 \\
(0.0-22.8)\end{array}$ & $\begin{array}{c}9.5 \pm 4,5 \\
(0.0-20.0)\end{array}$ & $\begin{array}{c}9.6 \pm 5.9 \\
(0.6-22.8)\end{array}$ & NS \\
\hline EBMIL [\%] & $\begin{array}{c}29.2 \pm 13.8 \\
(0.0-69.4)\end{array}$ & $\begin{array}{c}29.4 \pm 13.7 \\
(0.0-57.1)\end{array}$ & $\begin{array}{c}29.0 \pm 14.2 \\
(2.1-69.4)\end{array}$ & NS \\
\hline
\end{tabular}

Table IV. Incidence of comorbidities before and after IGB treatment

Tabela IV. Schorzenia i dolegliwości współwystępujące przed i po leczeniu metodą implantacji balonu wewnątrż̇ołądkowego

\begin{tabular}{|c|c|c|c|c|}
\hline Comorbidities & $\begin{array}{l}\text { Frequency } \\
\text { of occurrence } \\
\text { before IGB }\end{array}$ & $\begin{array}{l}\text { Frequency } \\
\text { of occurrence } \\
\text { after IGB }\end{array}$ & p-value & $\begin{array}{c}\text { Number of patients whose symptoms } \\
\text { subsided (\% in relations to starting } \\
\text { number) }\end{array}$ \\
\hline Hypertension & $59(79 \%)$ & $48(64 \%)$ & $<0.01$ & $11(19 \%)$ \\
\hline Type 2 diabetes & $25(33 \%)$ & $14(19 \%)$ & $<0.001$ & $11(44 \%)$ \\
\hline Hyperlipidaemia & $26(35 \%)$ & $23(31 \%)$ & NS & $3(12 \%)$ \\
\hline Spinal pain & $69(92 \%)$ & $56(75 \%)$ & $<0.001$ & $13(19 \%)$ \\
\hline Osteoarthritis & $45(60 \%)$ & $31(41 \%)$ & $<0.0001$ & $14(31 \%)$ \\
\hline Varicose veins of lower limbs & $23(31 \%)$ & $24(32 \%)$ & NS & - \\
\hline Dyspnoea during exercise & $36(48 \%)$ & $21(28 \%)$ & $<0.0001$ & $15(42 \%)$ \\
\hline Dyspnoea at rest & $4(5 \%)$ & $3(4 \%)$ & NS & $1(25 \%)$ \\
\hline Sleep apnoea & $36(48 \%)$ & $10(13 \%)$ & $<0.001$ & $26(72 \%)$ \\
\hline Menstrual disorders & $9(24 \%)$ & $3(8 \%)$ & $<0.05$ & $6(67 \%)$ \\
\hline Impotence & $12(32 \%)$ & $1(3 \%)$ & $<0.001$ & $11(92 \%)$ \\
\hline
\end{tabular}


IGB treatment and associated comorbidities $(\mathrm{p}=0.233$, V-squared-NS) either.

The incidence of complications in the course of obesity treatment by intragastric balloon implantation is presented in Table V.

Table V. Incidence of early and late complications during treatment with IGB Tabela V. Występowanie wczesnych i późnych powikłań podczas leczenia IGB

\begin{tabular}{lcc}
\hline \multicolumn{1}{c}{ Complications } & $\begin{array}{c}\text { Early (mild) } \\
\text { complication* } \\
\mathbf{n}(\%)\end{array}$ & $\begin{array}{c}\text { Late (sometimes } \\
\text { serious) } \\
\text { complications* } \\
\mathbf{n}(\%)\end{array}$ \\
\hline Nausea & $59(79 \%)$ & $13(17 \%)$ \\
Vomiting & $49(65 \%)$ & $16(21 \%)$ \\
Epigastric pain & $32(43 \%)$ & $9(12 \%)$ \\
Flatulence & $39(52 \%)$ & $19(25 \%)$ \\
Gastro-oesophageal reflux & $21(28 \%)$ & $9(12 \%)$ \\
Oesophageal candidiasis & $5(7 \%)$ & $3(4 \%)$ \\
Dehydration & $13(17 \%)$ & $6(8 \%)$ \\
General discomfort & $33(44 \%)$ & $15(20 \%)$ \\
$\begin{array}{l}\text { Acute gastritis resulting in } \\
\text { need for early balloon removal }\end{array}$ & - & $3(4 \%)$ \\
$\begin{array}{l}\text { Bursting of balloon (without } \\
\text { obstruction) with spontaneous }\end{array}$ & - & $3(4 \%)$ \\
excretion & & - \\
$\begin{array}{l}\text { Mechanical ileus, intestinal } \\
\text { obstruction caused by moving } \\
\text { balloon }\end{array}$ & - & - \\
Perforation of stomach & - & - \\
Death & - & - \\
\hline
\end{tabular}

* complications appearing a few hours after surgery, subsiding before end of second week of treatment

** complications occurring after second week of treatment and persisting up to 3 months or to end of treatment

\section{DISCUSSION}

According to the definition, multimorbidity is the simultaneous accidental occurrence of two or more diseases in one person, which are linked to each other by a pathogenic mechanism [16]. Multimorbidity is associated with chronic disorders that gradually lead to functional inefficiencies and thus negatively affect the quality of life. Among the direct causes, one can distinguish those that are related to the coexisting pathological states and drugs used. The second group of causes includes those that result from environmental conditions, including lifestyle. Obese people frequently have coexisting diseases such as hypertension, diabetes mellitus type 2, and dyslipidaemia, resulting in metabolic syndrome, heart and vascular diseases, gall bladder disease, fatty liver and fibrosis, degenerative arthritis, respiratory diseases including asthma and sleep apnoea, endocrine disorders, infertility, polycystic ovary syndrome in women, and hypogonadism in men. In addi- tion, there are mental and emotional disorders and some types of cancers. These diseases greatly impair health and contribute to premature death $[1,2,17,18,19,20]$. The focus of the study is on the goals of the National Health Program for 2016-2020 as a strategic response to the need to counteract negative epidemiological trends and the increasing burden on the population, of chronic non-communicable diseases to which obesity and its related diseases are classified.

The occurrence of multimorbidity in obese people is associated with higher rates of death, disability and adverse events, which is associated with more frequent use of medical care and institutionalized care by obese patients as well as a lower quality of life. Most clinical practice guidelines (CPGs) focus on the treatment of a single disease. When it comes to caring for obese patients with multimorbidity, this may prove to be inappropriate, not beneficial or even harmful. The imperfections of CPGs are not due to shortcomings in the development and implementation of the guidelines, but mainly because obese patients with multimorbidity are usually excluded or poorly represented in clinical and observational studies. This excludes the data on this group of patients from analysis in meta-analyses, systematic reviews and guidelines.

The described study has a number of limitations. First of all, the study group is small. In addition, we analysed patients only after six months of IGB treatment due to the other planned bariatric procedures, moreover, only from one hospital. A larger number of recruited patients observed within a wider period and from a larger number of medical centres will allow more accurate analysis to be performed on the existence of multimorbidity in obese patients in Poland, which will be the subject of further studies. Among other medical procedures, practicing this minimally invasive method of treating obesity significantly reduces the risk of future negative health effects of obesity and complications during possible surgical procedures, as well as shortens the time of hospitalization and allows early implementation of rehabilitation. With the number of diseases that occur, the risk of functional impairment increases. It is particularly high in people with morbid obesity because of the disease-related nature of the significant reduction in the functional reserve of all organs and the resulting high risk of multi-organ complications and loss of autonomy. The main aim of the study on the treatment of obesity by intragastric balloon implantation was to evaluate whether a reduction in excess weight may affect the remission or alleviation of comorbidities. According to various authors, weight reduction after implantation of the balloon in the stomach varies from 11 to 41.5 $\mathrm{kg}[21,22]$. In our study there was an average weight loss of $27.4 \mathrm{~kg}$. The pre-treatment BMI was $57.8 \mathrm{~kg} / \mathrm{m}^{2}$, and after six months it was $48.3 \mathrm{~kg} / \mathrm{m}^{2}$, which means that the average decrease was $9.6 \mathrm{~kg} / \mathrm{m}^{2}$. The observed mean decrease in BMI was greater by $4.7 \mathrm{~kg} / \mathrm{m}^{2}$ compared to the results obtained by Genco et al. [23]. This may be due to the lower average BMI of $44.4 \mathrm{~kg} / \mathrm{m}^{2}$ 
before IGB in those patients compared to our patients. On the other hand, the mean percentage of excess weight was $33.9 \pm 18.7 \%$ and it was slightly higher than that reported in our own study, which was 29.1 $\pm 13.7 \%$. Similar results were obtained by Mui et al. [24] in patients with a BMI $>40 \mathrm{~kg} / \mathrm{m}^{2}$ (mean $27.4 \pm$ $17.0 \%$ ). On the other hand Doldi et al. [21] in studies on a sample of 281 patients with a mean BMI of 41.8 $\mathrm{kg} / \mathrm{m}^{2}$ observed weight loss of $14 \mathrm{~kg}$ on average after six months of treatment using IGB and it was almost half of that obtained in our study.

Mitura and Garnysz [25] achieved an average of $41 \pm$ 19.6\% EWL, with an average pre-treatment BMI of $37.2 \pm 4.1$ and an average BMI reduction of $5.8 \mathrm{~kg} / \mathrm{m}^{2}$ over the recommended time of treatment. Mathus-Vliegen et al. [26,27] after IGB treatment observed a weight loss of 16.7 to $20 \mathrm{~kg}$. Göttig et al. [28] in 109 patients with an average BMI of $68.6 \mathrm{~kg} / \mathrm{m}^{2}$ achieved a mean decrease of $8.7 \mathrm{~kg} / \mathrm{m}^{2}$, with an average weight loss of $26.3 \mathrm{~kg}$ over 6 months. According to other authors, the mean BMI before IGB was $46.7 \mathrm{~kg} / \mathrm{m}^{2}$ and $43.1 \mathrm{~kg} / \mathrm{m}^{2}$ after treatment with an average decrease in BMI of $3.6 \mathrm{~kg} / \mathrm{m}^{2}$ [29]. Negrin-Dastis et al. [30] observed a mean change in weight loss of $12.6 \pm 8.3 \mathrm{~kg}$, corresponding to $38.3 \% \pm$ $26.9 \%$ excess body weight six months after balloon implantation. However, the good results could be due to frequent contact with a dietitian, which was an average of $4.9 \pm 2.8$ times during the treatment period.

The study did not investigate the issue of maintaining weight loss after treatment, mainly due to the fact that most patients were undergoing other bariatric procedures or had planned them in the future. Nonetheless, according to research, in overweight or obese people, weight loss $\geq 10 \%$ of the initial body weight is maintained after 2.5 years in $24 \%$ of patients [30]. Interesting results were obtained by Peker et al. [31] in a study intended to compare the outcomes of obesity treatment with a double endoscopic implantation of a balloon in the stomach. The study showed further progress in weight reduction on re-implantation. This may be an alternative for those patients who are not fully convinced of the surgical treatment but are aware of the health risks of being overweight.

In order to evaluate the regression of accompanying ailments and diseases, the data from patient records were used. The complaints and illnesses most frequently associated with obesity were assessed. Undoubtedly, positive results of obesity treatment by balloon implantation in the stomach were observed in 54 patients $(62.0 \%)$, which caused the relief or complete disappearance of pre-existing conditions and accompanying ailments. Genco et al. [23], reported preoperative comorbidities in 1394 patients $(56.4 \%)$. The treatment resulted in an overall improvement in the health status of 617 patients $(44.3 \%)$. In another 625 patients $(44.8 \%)$, improvement was achieved by lowering the dose of co-morbid medication in the pharmacological treatment used, while in the remaining 152 patients $(10.9 \%)$ no remission or relief of comorbidities was observed [23]. The results from our own studies demonstrate the beneficial effect of the treatment method used in $62.0 \%$ of patients, as was the case with Göttig et al. [28], who observed an improvement of $56.8 \%$. The greatest improvement in health status observed in our study was in the case of sleep-disordered breathing in 26 patients $(72.0 \%)$. Weight reduction has also been shown to have a beneficial effect on abnormal breathing during exercise, which can be affected by many factors in overweight and obese people, including the lack of physical activity. There were also positive effects in such major diseases as hypertension, which normalized in $19 \%$ of the subjects or type 2 diabetes in $44 \%$ of the patients, and hyperlipidaemia in $12 \%$ patients. In a multicentre study, the prevalence of underlying hypertension was resolved in $13 \%$ of subjects, type 2 diabetes in $5 \%$ of subjects, and hyperlipidaemia in $11 \%$ [32]. Using the BAROS scale criteria, the study showed that 21 patients $(28 \%)$ had no health improvement, which does not mean that the applied treatment did not improve their health at all. Despite the BAROS scale adopted in the study, its authors, Orie and Moorehead [15], cast doubt on its use in patients with super obesity (BMI $>50 \mathrm{~kg} / \mathrm{m}^{2}$ ), for three reasons: (1) it cannot be expected that patients will achieve a normal body weight for BMI 25, (2) the impact of genetic factors in super obese patients may be stronger than in other groups of obese people, (3) the lack of statistical data indicating the degree of necessary weight reduction in people with super obesity to define the optimal outcome of treatment for the comorbidities. Awareness of this leads to more cautious acceptance of conclusions resulting from research and warns against uncritical generalization of them to the entire obese population.

Although most experts in practice do not encounter complications in IGB treatment, there are early (mild) and late (sometimes serious) complications that can be life-threatening for the patient. The most common mild reactions to the presence of a balloon are nausea, vomiting, heartburn, bloating and contractions. Heaviness in the abdomen, abdominal or back pain, gastro-oesophageal reflux disease and dyspepsia are the most common temporary symptoms, treatable with proton pump inhibitors or anti-emetics. Nevertheless, sometimes untreated, long-lasting vomiting can lead to dehydration and serious metabolic complications. Vomiting is the most common complication after bariatric procedures as well as after IGB and may occur in over $70 \%$ of patients. They can be a response to the problem of consuming too much food at once, or prohibited types of food and complications caused by the surgery itself $[33,34]$.

In the authors' own studies, nausea was the most common complication in 59 people $(79 \%)$ and vomiting in 49 people $(65 \%)$. In the Evans and Scott study [34], vomiting occurred in more than half of the treated (31 patients) and was the most common early complication. Dangerous complications can occur during endoscopy, and during placing or removing the balloon. An excessive reaction to intravenous sedation may cause respira- 
tory failure, while the risk of aspiring stomach contents or the balloon can occur when placing or removing the balloon [35]. Mechanical injuries to the throat, oesophagus or the stomach wall can lead to bleeding, esophagitis, Malory-Weiss syndrome and even perforation requiring surgical correction [36,37]. During implantation of the balloon it is possible to improperly introduce it; increased pressure may lead to erosion or ulceration of the gastric mucosa. The formation of gastric ulcers induced by the presence of the balloon is justified by the mechanical irritancy of the stomach wall. Food lodged between the balloon and the stomach wall or catching on the rigid and irregular surface of the valve can increase the pressure of the stomach wall, creating weakened zones and eventually lead to perforation. Periodic perforations were reported in patients undergoing previous upper gastrointestinal surgery, which is why it constitutes an absolute contraindication to gastric balloon implantation $[23,38]$. A serious complication is migration of the balloon caused by its perforation or leak, which can cause intestinal obstruction, requiring endoscopic or surgical removal [36]. In the present work, complete balloon intolerance, resulting in the necessity for its earlier removal, was observed in three people, while Evans and Scott [34] report complete balloon intolerance in four cases. Among 58 patients, the balloon was dislocated in 18 , and three patients underwent laparotomy to restore bowel patency. In 3 of our patients $(4 \%)$ the balloon broke and was spontaneously evacuated from the gastrointestinal tract without the necessity for its endoscopic or surgical removal, while in one of the patients only during the follow-up in the third month of treatment was the lack of a balloon in the stomach discovered in the ultrasound examination, and the remaining patients reported observing a change in the colour of the urine due to the methyl-blue added to the physiological saline in the balloon.

Genco et al. [23] conducted a study on the effectiveness of IGB therapy in 2,515 patients. The overall complication rate in the above study was $2.8 \%(\mathrm{n}=70)$. Gastrointestinal perforation occurred in five patients $(0.19 \%)$, of which four had previously gastric surgery. Two people died. In 9 cases $(0.36 \%)$, the balloon burst. Esophagitis was recorded in 32 people (1.27\%) and gastric ulcer in $5(0.2 \%)$. Mathus-Vliegen and Tytgat [36] observed that in a group of 43 patients resistant to conservative treatment there were three cases of balloon intolerance $(7.0 \%)$, manifested by a serious inflammation of the oesophagus, and three consecutive patients developed gastritis, which was associated with the use of non-steroidal anti-inflammatory drugs. Sudden, intense abdominal pain, even a few weeks or months after implantation of the balloon in the stomach should arouse suspicion of perforation of the stomach. In the medical literature there are several described cases of gastric perforation, one case of short-term hypoxia when removing the balloon $[23,38]$ and two documented cases of death $[39,40]$. Two deaths occurred in our own studies; however, their immediate cause was cardiorespiratory failure associated with complications of the comorbidities. A further four patients died in the period after the end of treatment, and the causes of deaths reported by the families concerned complications of chronic non-communicable diseases. Negrin-Dast et al. [30] observed two deaths due to cardiorespiratory failure 5 years after balloon implantation.

Caring for an obese person with multimorbidity should take into account all the aspects of the illness. To ensure such care, a team of specialists is needed to provide comprehensive diagnostics and therapies focused on functional efficiency, which must cover a wide range of activities, from preventative to bariatric surgery.

Patients with a functional disability or significant risk of disease require therapy to be preceded by prioritization of treatment goals, followed by actions to reduce deficits, starting from the most important areas for the patient. Multimorbidity hampers prevention, as each pathology should independently consider the indications and contraindications to specific types of action, and then take them into account in the prepared treatment regimens.

\section{CONCLUSIONS}

1. Treatment by endoscopic implantation of the intragastric balloon alleviates the course or reduces the incidence of concomitant diseases in persons with morbid obesity.

2. The method of endoscopic implantation of an intragastric balloon is an effective method of reducing excess body weight in people with morbid obesity.

3. IGB treatment can be used to reduce the risk of perioperative complications due to significant weight loss and a reduced incidence of multimorbidity.

\section{Author's contribution}

Study design - K. Krupa-Kotara, K. Sosada

Data collection - K. Krupa-Kotara

Data interpretation - K. Krupa-Kotara, S. Kotara, M. Olejniczak-Nowakowska

Statistical analysis - K. Krupa-Kotara

Manuscript preparation - K. Krupa-Kotara, S. Kotara

Literature research - K. Krupa-Kotara, M. Olejniczak-Nowakowska

Translation - S. Kotara

Final approval of the version to be published - K. Sosada, K. Krupa-Kotara, S. Kotara 


\section{REFERENCE}

1. Haslam D.W., James W.P. Obesity. Lancet 2005; 366 (9492): 1197-1209. 2. World Health Organization. Global health risks: mortality and burden of disease attributable to selected major risks. Geneva; 2009: 9-31.

3. World Health Organization. Obesity and overweight. Facts sheet $N^{\circ} 311$ 2015 [Dostęp: 4.05.2017].

4. Finkelstein E.A., Khavjou O.A., Thompson H., Trogdon J.G., Pan L., Sherry B., Dietz W. Obesity and severe obesity forecasts through 2030. Am. J. Prev. Med. 2012; 42: 563-570, doi: 10.1016/j.amepre.2011.10.026.

5. Stanowski E., Wyleżoł M., Paśnik K. Laparoskopia w chirurgii bariatrycznej w Polsce - stan aktualny. Wideochir. Inne Tech. Maloinwazyjne 2007: 2(1) $18-23$.

6. Sjöström L., Narbro K., Sjöström C.D., Karason K., Larsson B., Wedel H., Lystig T., Sullivan M., Bouchard C., Carlsson B., Bengtsson C. et al. Effects of bariatric surgery on mortality in Swedish obese subjects. N. Engl. J. Med. 2007; 357(8): 741-752, doi: 10.1056/NEJMoa066254.

7. Sjöström L. Review of the key results from the Swedish Obese Subjects (SOS) trial - a prospective controlled intervention study of bariatric surgery. J. Intern. Med. 2013; 273(3): 219-234, doi: 10.1111/joim.12012.

8. Wylezol M.S., Zwirska-Korczala K., Pasnik K. Bariatric surgery in Polan from 1993 to 2003. J. Physiol. Pharmacol. 2005; 56(6): 109-115.

9. Abell T.L., Minocha A. Gastrointerstinal complications of bariatric surgery: diagnosis and therapy. Am. J. Med. Sci. 2006; 331(4): 214-218, doi 10.1097/00000441-200604000-00008.

10. Hu B., Chug S.C.S., Sun L.C.L., Kawashima K., Yamamoto T., Cotton P.B., Gostout C.J., Hawes R.H., Kalloo A.N., Kantsevoy S.V., Pasricha P.J. Transora obesity surgery: Endoluminal gastroplasty with an endoscopic suture device. Endoscopy 2005; 37(5): 411-414, doi: 10.1055/s-2005-861196.

11. Żurawiński W., Sosada K., Jopek J., Piecuch J., Mazur I. Endoskopowe leczenie otyłości z zastosowaniem balonu dożołądkowego. Pol. Przegl. Chir 2010; 82(7): 754-761.

12. Buchwald H., Oien D.M. Metabolic/bariatric surgery worldwide 2011 Obes. Surg. 2013; 23(4): 427-436, doi: 10.1007/s11695-012-0864-0.

13. Dumonceau J.M. Evidence-based review of the bioenterics intragastric balloon for weight loss. Obes. Surg. 2008; 18(12): 1611-1617, doi: 10.1007 / s11695-008-9593-9.

14. Fred M., Hainer W., Basdevant A. et al. Interdisciplinary European guidelines on surgery of severe obesity. Obesity Facts 2008; 1: 52-59, doi: $10.1159 / 000113937$.

15. Oria H.E., Moorehead M.K. Bariatric analysis and reporting outcome system (BAROS) Obes. Surg. 1998; 8(5): 487-499, doi: 10.1381/096089298765554043

16. Wallace E., Salisbury C., Guthrie B., Lewis C., Fahey T., Smith S.M. Managing patients with multimorbidity in primary care. BMJ 2015; 350: h176, doi: 10.1136/bmj.h176

17. Jędrzejuk D., Milewicz A. Nadwaga i otyłość. [W:] Choroby serca i naczyń Poradnik lekarza rodzinnego. Red. G. Opolski, W. Lukas, A. Steciwko. Via Medica. Gdańsk 2007; 5161.

18. Chen Z.A., Roy K., Gotway Crawford C. Obesity prevention: the impact of local health departments. Health Serv. Res. 2013; 48(2 Pt 1): 603-627, doi: 10.1111/j.1475-6773.2012.01447.x.

19. Buksińska-Lisik M., Lisik W., Zaleska T. Otyłość - choroba interdyscyplinarna. Przew. Lek. 2006; 9(1): 72-77.

20. Karam J., McFarlane S. Tackling obesity: new therapeutic agents for assisted weight loss. Diabetes. Metab. Syndr. Obes. 2010; 3: 95-112.

21. Doldi S.B., Micheletto G., Di Prisco F., Zappa M.A., Lattuada E., Reitano M. Intragastric balloon in obese patients. Obes. Surg. 2000; 10: 578-581, doi: $10.1381 / 096089200321594200$

22. Żurawiński W., Sokołowski D., Krupa-Kotara K., Czech E., Sosada K. Evaluation of the results of treatment of morbid obesity by the endoscopic intragastric balloon implantation method. Wideochir. Inne Tech. Maloinwazyjne 2017; 12(1): 37-48, doi: $10.5114 /$ wiitm.2017.66856.

23. Genco A., Bruni T., Doldi S., Forestieri P., Marino M., Busetto L., Giardiello C., Angrisani L., Pecchioli L., Stornelli P., Puglisi F. et al. Bioenterics intragastric balloon: The Italian experience with 2515 Patients. Obes. Surg. 2005; 15(8): 1161-1164, doi: 10.1381/0960892055002202.

24. Mui W.L., Ng E.K., Tsung B.Y., Lam C.H., Yung M.Y. Impact on obesityrelated illnesses and quality of life following intragastric balloon. Obes. Surg. 2010; 20(8): 1128-1132, doi: 10.1007/s11695-008-9766-6.

25. Mitura K., Garnysz K. Tolerance of intragastric balloon and patient's satisfaction in obesity treatment. Wideochir. Inne Tech. Maloinwazyjne 2015; 10(3): 445-449, doi: 10.5114/wiitm.2015.54047.

26. Mathus-Vliegen E.M., Tytgat G.N., Veldhuyzen-Offermans E.A. Intragastric balloon in the treatment of super-morbid obesity. Double-blind, sham-controlled, crossover evaluation of 500-milliliter balloon. Gastroenterology 1990; 99(2): 362-369, doi: 10.1016/0016-5085(90)91017-z.

27. Mathus-Vliegen E.M.H. Efficacy of bioenterics intragastric balloon treatment in a prospective 2 years follow-up study. Presented at the Eighth European Congress on Obesity; 1997 Aug. Dublin, Ireland: European Congress on Obesity, 1997.

28. Göttig S., Daskalakis M., Weiner S., Weiner R.A. Analysis of safety and efficacy of intragastric balloon in extremely obese patients. Obes. Surg. 2009; 19(6): 677-683, doi: 10.1007/s11695-009-9820-z.

29. Al Kahtani K., Qaseem Khan M.Q., Helmy A., Al Ashgar H., Rezeig M., Al Quaiz M., Kagevi I., Al Sofayan M., Al Fadda M. Bio-enteric intragastric balloon in obese patients: A retrospective analysis of King Faisal Specialist Hospital Experience. Obes. Surg. 2010; 20: 1219-1226, doi: 10.1007/s11695008-9654-0

30. Dastis S.N., François E., Deviere J., Hittelet A., Ilah Mehdi I.A., Barea M., Dumonceau J.M. Intragastric balloon for weight loss: results in 100 individuals followed for at least 2.5 years. Endoscopy 2009; 41(7): 575-580, doi: $10.1055 / \mathrm{s}-0029-1214826$.

31. Peker Y., Coskun H., Bozkurt S., Cin N., Atak T., Gencdoi H. Comparison of results of laparoscopic gastric banding and consecutive intragastric balloon application at 18 months: a clinical prospective study. J. Laparoendosc. Adv. Surg. Tech. A 2011; 21(6): 471-475, doi: 10.1089/lap.2010.0439.

32. Genco A., López-Nava G., Wahlen C., Maselli R., Cipriano M., Mara Arenas Sanchez M., Jacobs C., Lorenzo M. Multi-centre European expe-rience with intragastric balloon in overweight populations: 13 years of experience. Obes. Surg. 2013; 23(4): 515-521, doi: 10.1007/s11695-012-0829-3.

33. Zheng Y., Wang M., He S., Ji G. Short-term effects of intragastric balloon in association with conservative therapy on weight loss: a meta-analysis. J. Transl. Med. 2015; 13: 246, doi: 10.1186/s12967-015-0607-9.

34. Evans J.D., Scott M.H. Intragastric balloon in the treatment of patients with morbid obesity. Br. J. Surg. 2001; 88(9): 1245-1248, doi: 10.1046/j.0007$-1323.2001 .01840 . x$

35. Pretolesi F., Redaelli G., Papagni L., Derchi L.E. Intragastric balloon for morbid obesity causing chronic gastric dilatation. Eur. Radiol. 2001; 11(4); 588-589, doi: $10.1007 / \mathrm{s} 003300000629$.

36. Mathus-Vliegen E.M., Tytgat G.N. Intragastric balloon for treatment-resistant obesity: safety, tolerance, and efficacy of 1-year balloon treatment followed by a 1-year balloon-free follow-up. Gastrointest Endosc 2005; 61(1): 19-27, doi: 10.1016/s0016-5107(04)02406-x.

37. Nijhof H.W., Steenvoorde P., Tollenaar R.A. Perforation of the esophagus caused by the insertion of an intragastric balloon for the treatment of obesity. Obes. Surg. 2006; 16(5): 667-670, doi: 10.1381/096089206776944887. 38. Giardiello C., Cristiano S., Cerbone M.R., Troiano E., Iodice G., Sarrantonio G. Gastric perforation in an obese patient with an intragastric balloon, following previous fundoplication. Obes. Surg. 2003; 13(4): 658-660, doi: $10.1381 / 096089203322190925$.

39. Ballare M., Orsello M., Del Piano M. A case of death after insertion of an intragastric balloon for treatment of morbid obesity. Dig. Liver Dis. 2004; 36(7): 499, doi: 10.1016/j.dld.2004.03.005.

40. Koutelidakis I., Dragoumis D., Papaziogas B., Patsas A., Katsougianopoulos A., Atmatzidis S., Atmatzidis K. Gastric perforation and death after the insertion of an intragastric balloon. Obes. Surg. 2009; 19: 393-396, doi: 10.1007/ s11695-008-9706-5. 